\title{
Nanotechnology among Teachers and Students in the Arab Sector in Israel: Awareness and Attitudes
}

\author{
Riam Abu Much, Ahmad Basheer, Sufian Zahaika, Muhamad Hugerat* \\ The Academic Arab College for Education in Israel-Haifa, Haifa, Israel \\ Email: ^Muha4@arabcol.ac.il
}

How to cite this paper: Much, R. A., Basheer, A., Zahaika, S., \& Hugerat, M. (2019). Nanotechnology among Teachers and Students in the Arab Sector in Israel: Awareness and Attitudes. Creative Education, 10, 1140-1154.

https://doi.org/10.4236/ce.2019.106086

Received: March 26, 2019

Accepted: June 15, 2019

Published: June 18, 2019

Copyright $\odot 2019$ by author(s) and Scientific Research Publishing Inc. This work is licensed under the Creative Commons Attribution International License (CC BY 4.0).

http://creativecommons.org/licenses/by/4.0/

\begin{abstract}
The present study investigates awareness and attitudes towards nanotechnology among teachers and students from the Arab sector in Israel. The research was based on distributing a questionnaire and a semi-structured interview. The results revealed that both the teachers and students have a basic knowledge of nanotechnology. Moreover, different variables including gender, grade, years of experience, and level of education, have revealed no effect, considering the fact that nanotechnology is not introduced as a subject in teaching curriculum in schools.
\end{abstract}

\section{Keywords}

Nanotechnology, Nanoscience, Awareness, Attitudes, Knowledge,

Questionnaire, Semi-Structured Interview, Arab Sector

\section{Introduction}

Nanoscience is an interdisciplinary field that deals with materials, structures, and devices at the nanoscale. The origin of the word Nano is Greek and means dwarf. Mathematically, Inanometer is equal to $10^{-9} \mathrm{~m}$. At this scale, properties of materials change dramatically from the familiar macroscale ones. Nanotechnology means putting to use the unique physical properties of atoms, molecules, and structures measuring roughly $1-1000 \mathrm{~nm}$ that has applications in the real life (Bhushan, 2010). The advancement of nanoscience and nanotechnology are leading to a technological revolution in human life; these advances have had a significant qualitative impact on science (Wacker, 2014). Nanotechnology is a rapidly evolving science of understanding and controlling matter that is having profound implications on many different fields due to its interdisciplinary cha- 
racter and by offering new opportunities at the nano dimension. It is bringing about new perspectives on the chemical, environmental, biomedical, electronics, automotive and aerospace industries at the nano-scale that have a unique surface, catalytic and magnetic properties that were once considered impossible (Ekli \& Sahin, 2013).

The importance of nanoscience and nanotechnology, and its positive effect on the technological and medical developments, obligate us to raise the awareness and knowledge about it in order to be in parallel with scientific advancements. We believe that schools are the first starting point. That means, creating future generation with sufficient scientific awareness and parallel to the leading scientific developments. In 1852 John Dewey stated "If we teach today's students as we taught yesterday's, we rob our children of tomorrow." However, it is well known that often teachers teach as they were taught. As Putnam \& Borko (2000) explained: "How a person learns a particular set of knowledge and skills, and the situation in which a person learns, become a fundamental part of what is learned." (Putnam \& Borko, 2000). To achieve this goal, it is desired to examine as the first step the awareness, knowledge, and attitudes towards nanosciense and nanotechnology among teachers and students. In this article we focused on the Arab sector in Israel which represents about $20 \%$ of Israel's population.

Teachers' perceptions and knowledge about nanotechnology can influence their approach to science education, and their teaching behavior as this is considered as one of the key emerging interdisciplinary areas of the $21^{\text {st }}$ century. According to Abd-El-Khalick (2001), Teachers' perceptions, beliefs, attitudes and understandings concerning the emerging technologies can influence their approach to science teaching and even their teaching behaviors. Therefore, teachers, as well as candidate teachers, should be informed about the different aspects of nanotechnology through in-service training, seminars, model activities, and projects (Ekli \& Sahin, 2010).

Nanotechnology education is proposed by a large number of universities around the world in Bachelor, Master, and Ph.D. studies. Generally, it involves a multidisciplinary natural science education with courses in nanotechnology, physics, chemistry, math and molecular biology (Joachim, 2004).

According to Roco (2003), a key challenge for nanotechnology development is the education and training of a new generation of skilled workers. Such education and training must be introduced at all levels, from kindergarten to continuing education, from scientists to nontechnical audiences that may decide the use of technology and its funding. It is estimated that about 2 million nanotechnology workers were needed worldwide by 2015 (Roco \& Bainbridge, 2005).

Several studies reveal that the majority of the public have low awareness or knowledge about nanotechnology. General public surveys regarding awareness about nanotechnology have been carried out in a number of countries, Japan, USA, UK, Germany, Iran, Italy, and Australia. Although the surveys were car- 
ried out in different years ranging from 2004 to 2011, all of these countries have high literacy rates. Kahan (2009) involving 1850 Americans showed that $81 \%$ of the participants have no idea about nanotechnology. Similarly, a recent study conducted in Iran has shown that the majority of people are still not familiar with the concept of nanotechnology (Farshchi, Sadrnezhaad, Nejad, Mahmoodi, \& Abadi, 2011). A study performed by Ho and others (Ho, Scheufele, \& Corley, 2011) suggested that the more people know about nanotechnology, the more likely to hold positive attitudes towards it.

Waldron and others (Waldron, Spencer, \& Batt, 2006) have also found limited understanding of nanotechnology, as $60 \%$ of their research participants between the age of 15 - 59 were only familiar with the term "nano" and associated it with something small. Children under the age of 14 and those adults 60 and over were the least familiar with nanotechnology.

A study conducted by Elmarzokiand others (Elmarzugi et al., 2014) about the "Awareness of Libyan Students and Academic Staff Members of Nanotechnology", based on a survey collected randomly from many campuses of Tripoli University (Alfateh), and two governmental research centers (polymer and plastic) in Tripoli over a period of about five months (March - July), founded that of 330 participants, 156 knew about nanotechnology and 174 have no idea. A study conducted by Toqeer and others (Toqeer et al., 2015) in Pakistan, revealed that the majority of the respondents (77\%) had heard about nanotechnology but only (47\%) had read about it and a slightly lower percentage (44.4\%) had an awareness of the applications of nanotechnology. Elki and Sahin (2013) investigate Turkish middle school students' awareness, factual knowledge, opinions, and risk perceptions toward nanotechnology, the results show that there is no significant difference between male and females. However, for some of the demographic and affective domain factors, and achievement in science courses, significant differences were found.

\section{Research Questions and Hypothesis}

The present study, examine the awareness and attitudes of teachers and students from the Arab communities in Israel towards nanotechnology.

The following research questions were addressed:

1) What is teachers' awareness towards Nanotechnology?

2) What is students' awareness towards Nanotechnology?

3) What are the attitudes of the teachers toward Nanotechnology?

4) What are the attitudes of the students toward Nanotechnology?

Research questions were arises owing the fact that Israeli teaching curriculum in schools does not include the basic concepts of nanoscience and nanotechnology (Hofstein, Shore, \& Kipnis, 2004). This fact has motivated us to examine the extent of knowledge of teachers and students towards one of the bright scientific topics of the present age. Do participants have a high education outside the curriculum? Alternatively, are they limited to the curriculum subjects? 
Teachers and students' knowledge and attitudes were examined as a function of different factors includes gender, grade, level of education, and the number of years of experience. In considering the teachers, we believed that investigating the knowledge and attitudes of them toward nanosciense and nanotechnology could not be completed without taking into consideration the effect of these different factors that could affect teachers' qualification. Our expectations are that the participants have very limited knowledge about nanotechnology but they do have high motivation to acquire more information and be more qualified.

We argue that:

H1: Teachers have basic knowledge concerning Nanotechnology

H2: Students have basic knowledge concerning Nanotechnology

H3: Students have positive attitudes toward Nanotechnology

H4: Teachers have positive attitudes toward Nanotechnology

\section{Research Method}

The participants of this research were randomly selected teachers and students from the Arab sector in Israel. They represent about $20 \%$ of Israel's population. All schools in Israel belong to the Israeli educational system (Abu-Asbah, 2007). Arab schools are managed by Arab principals; the teaching language is Arabic, but the schools are subjugated to the Israeli educational system in both administrative (which include funding) and curricular aspects (Abu-Asbah, 2007; Arar, 2012).

Education is important to Arabs. There is a high awareness in the Arab population in Israel of the need and importance of providing higher education to the younger generation. This stems from the belief that education will secure social mobility for that generation at both the individual and collective levels (A'li \& Da'as, 2016). Education laws were legislated when the State of Israel was established in 1948, including provisions for compulsory education of all citizens of the state without distinction between nationalities or religions (Abu-Saad, 2006). Secondary schools belong to the education system, however, managed by the municipality. In 11 - 12 classes, students have to choose a profession specialization.

The education system in Israel is based on democratic and western values, which encourage open discussion and opinion.

The total number of participants consists of 120 students from $10^{\text {th }}, 11^{\text {th }}$, and $12^{\text {th }}$ grades selected randomly from five local high schools in East Jerusalem, and 70 science teachers. The teachers were distributed as follows: 40 males, and 30 females, whereas students consist of 65 males, and 55 females.

\subsection{Research Variables}

Dependent Variables: Awareness and Attitudes toward Nanotechnology among teachers and students in the Arab Sector in Israel.

Independent Variables: 

1) Gender
2) School type: Governmental, or Private
3) Educational level of teachers
4) Students' grade
5) Years of experience for teachers

\section{Data Analysis}

The participants were asked to answer a questionnaire that solicits the knowledge and attitudes of nanotechnology. It was adapted from Norwegian Relevance of Science Education Project (ROSE) questionnaire (Sjøberg \& Schreiner, 2010); Concepts of science and technology were replaced by nanotechnology and nanoscience. The questionnaire had three parts. The first part is about the demographic data of the participants. The second part consists of three open questions pertained to awareness and knowledge about nanotechnology, and it is relative to our everyday life. The third part concerns to participant's attitudes toward nanotechnology, this part was based on a five point Likert-types scale (Likert, 1932) scoring as $5=$ strongly agree to $1=$ strongly disagree. The participants were asked to answer 14 questions concerning different aspects related to nanotechnology. The questionnaire was validated and its reliability was in accordance with generally accepted academic standards. The questionnaire was translated into Arabic to fit the study sample. In addition to the questionnaire, semi-structured interviews were conducted (the qualitative part of the study) with randomly selected teachers and students.

\section{Results}

The results were analyzed using SPSS statistical analysis software. ANOVA analysis was used to identify differences between variables, and to determine whether our hypothesis was confirmed.

\subsection{Demographic Data of the Participants (Teachers, and Students)}

Based on the data from the questionnaire, demographic data of the teachers and students are summarized in Table 1 and Table 2 respectively.

According to Table 1 and Table 2, the high percentage of the students are studying in governmental schools. Moreover, most of the teachers have B.A or B.A + Diploma $(42.9+22.9=65.8 \%)$ and $61.4 \%$ have less than 5 years of experience.

\subsection{Teachers' and Students' Awareness and Knowledge toward Nanotechnology}

In order to determine participants' awareness and knowledge about nanotechnology, they asked to answer three open questions as follows:

Question 1: Write what do you know about Nanotechnology? 
Table 1. Demographic data of the participated teachers.

\begin{tabular}{cccc}
\hline & Variables & Frequency & Percent (\%) \\
\hline \multirow{3}{*}{ Gender } & Male & 40 & 57.1 \\
& Female & 30 & 42.9 \\
\multirow{2}{*}{ School } & Governmental & 52 & 74.3 \\
& Private & 18 & 25.7 \\
\multirow{2}{*}{ Educational level } & B.A & 24 & 34.3 \\
& B.A + Diploma & 30 & 42.9 \\
Experience & M.A and more & 16 & 22.9 \\
\hline
\end{tabular}

Table 2. Demographic data of the participated students.

\begin{tabular}{cccc}
\hline & Variables & Frequency & Percent (\%) \\
\hline \multirow{3}{*}{ Gender } & Female & 55 & 45.8 \\
& Male & 65 & 54.2 \\
\multirow{3}{*}{ Grade } & $10^{\text {th }}$ & 34 & 28.3 \\
& $11^{\text {th }}$ & 65 & 54.2 \\
\multirow{2}{*}{ School } & $12^{\text {th }}$ & 21 & 17.5 \\
& Governmental & 91 & 75.8 \\
\hline
\end{tabular}

Based on the answers of both teachers and students, we divided it into different categories as shown in Figure 1 and Figure 2 respectively.

Figure 1 and Figure 2 show that the majority of the students and teachers do aware that nanotechnology deals with small things, a frequency of 50 for teachers, and 71 for students. Moreover, a high frequency also mention its importance in medical and technological applications. Whereas, the lowest frequency is detected for teachers and students who have no idea about nanotechnology.

Question 2: Describe examples of Nanotechnology used in everyday life?

The answers of teachers, and students regarding the second question were summarized in Figure 3 and Figure 4 respectively.

According to Figure 3 and Figure 4 the answers of both teachers and students are encouraging. The majority of them aware about importance of nanotechnology for medical and technological applications, whereas, a lower frequency detected related to no answer, or don't know.

Question 3: What sort of jobs or tasks do you think nonscientists would do when they are working?

The response of teachers and students are summarized in Table 3 and Table 4 respectively. The answers are very general; they lack a specification of working field. Relating the teachers' answers, a frequency of 52 did not refer to any specified job, and a frequency of 37 refers to general answer of "solving problems and 
make life easier". The student's responses indicate a complete lack of knowledge of the areas of work in nanotechnology.

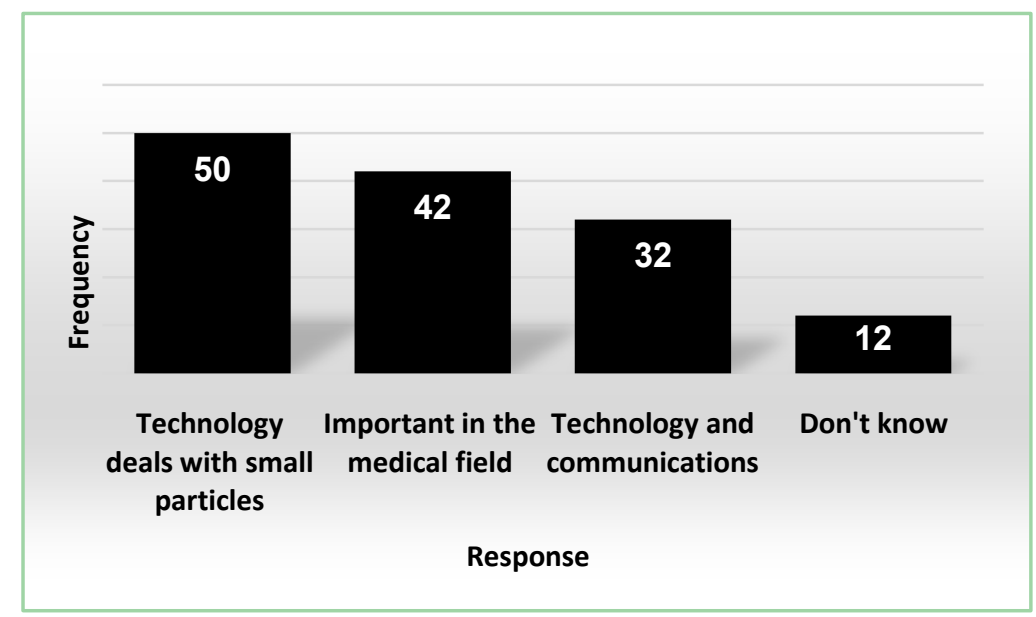

Figure 1. Answers of teachers regarding their knowledge about nanotechnology.

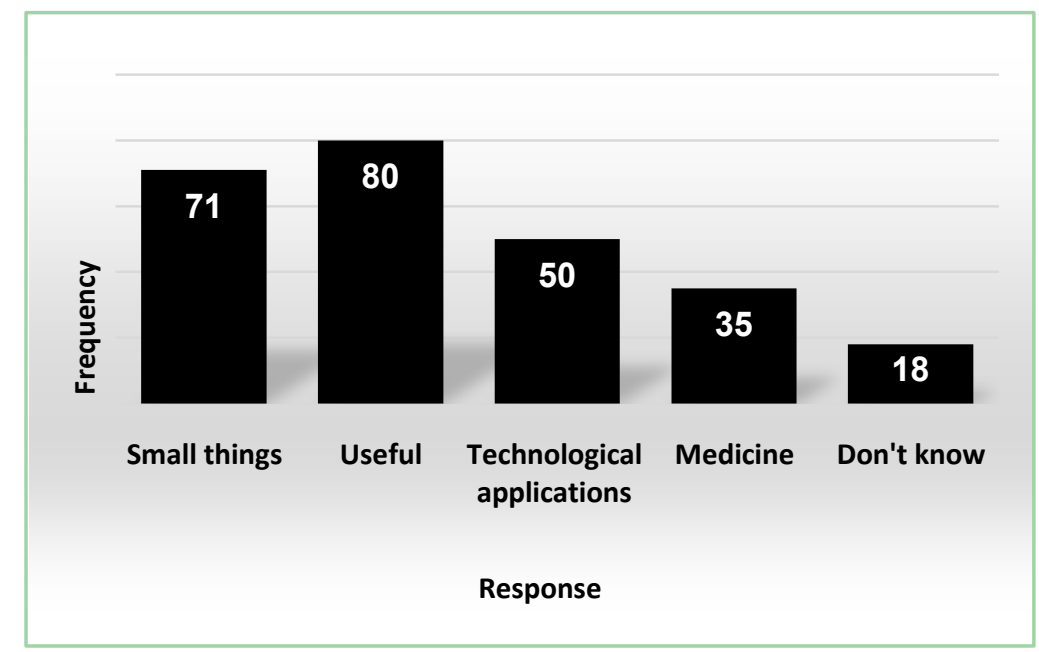

Figure 2. Answers of students regarding their knowledge about nanotechnology.

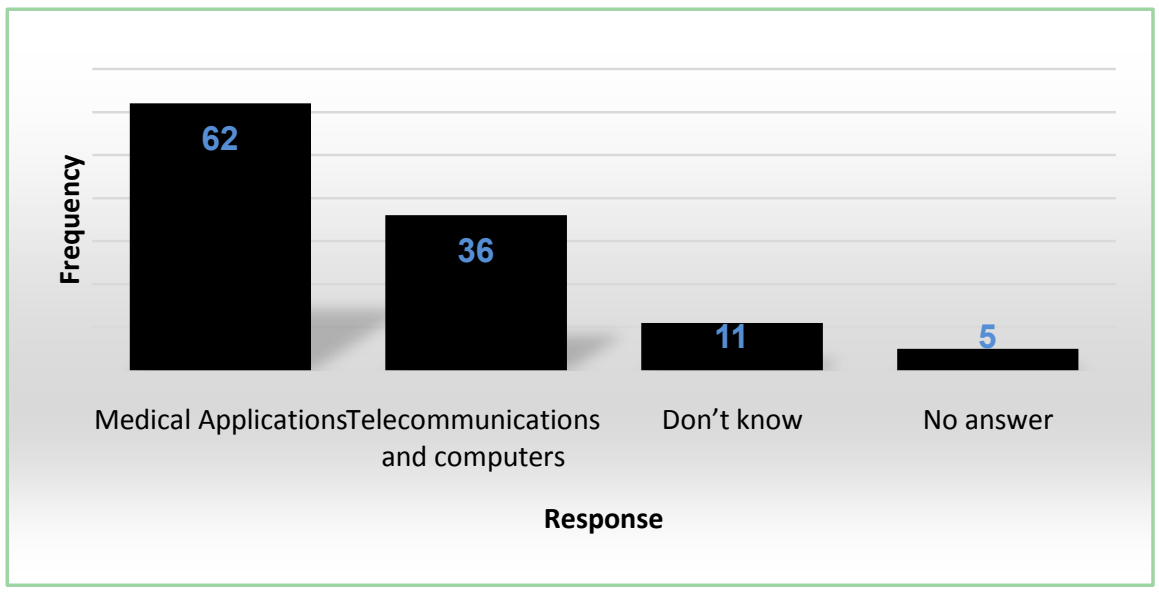

Figure 3. Answers of teachers regarding nanotechnology in everyday life. 


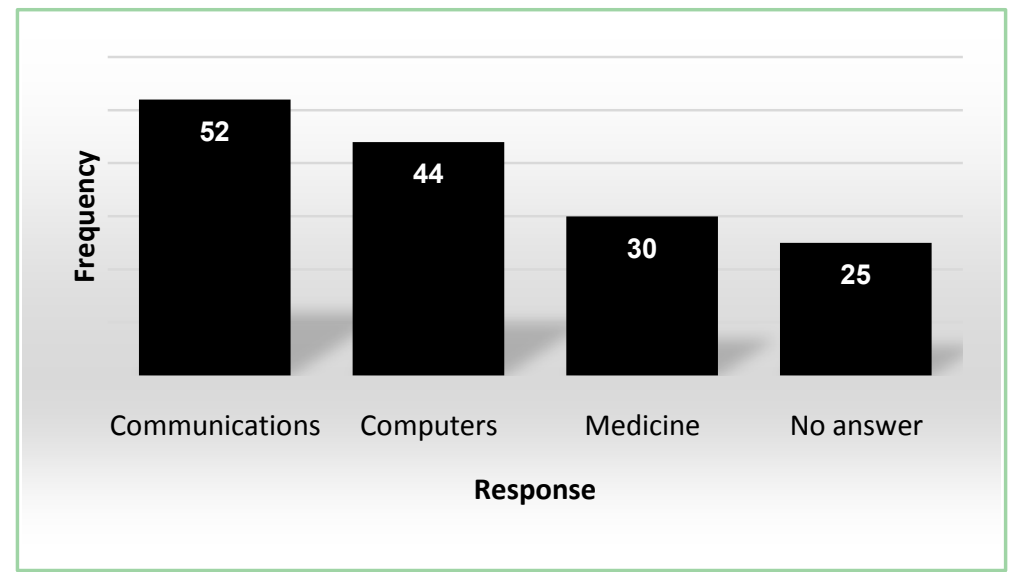

Figure 4. Answers of students regarding nanotechnology in everyday life.

Table 3. Answers of teachers regarding the third question.

\begin{tabular}{cc}
\hline Answers & Frequency \\
\hline Finding new applications & 52 \\
$\begin{array}{c}\text { Discover how to solve people } \\
\text { problems and make life easy } \\
\text { No answer }\end{array}$ & 37 \\
\hline
\end{tabular}

Table 4. Answers of students regarding the third question.

\begin{tabular}{cc}
\hline Answers & Frequency \\
\hline Make small things & 43 \\
Don't know & 40 \\
No answer & 30 \\
\hline
\end{tabular}

\subsection{Attitudes of Teachers and Students toward Nanotechnology}

As mentioned before, participants' attitudes were based on a five point $\mathrm{Li}$ kert-types scale. A t-test and ANOVA were used to identify differences between variables and to determine whether the research hypothesis were confirmed. Percentages (\%), arithmetic means, and std. deviation (s) were calculated. Table 5 and Table 6, present the results for teachers and students respectively.

The results show a similarity between teachers' and students' attitudes toward nanotechnology. Their knowledge is considered as "medium" with $\mathrm{n}=70$, $55.6 \%, \mathbf{x}=2.78$ for teachers, and $\mathrm{n}=120,51.0 \%, \mathbf{x}=2.55$ for students.

\subsubsection{Responses with Respect to Gender}

According to Table 7 and Table 8, among the 70 teachers, 40 were male and 30 were female. With arithmetic means 2.80 , and 2.75 for male and female respectively, there is no difference between their attitudes towards nanotechnology ( $\mathrm{p}$ $=0.703>0 / 05)$. Of the 111 students responded, 55 were male and 56 were female, similar results were obtained, with $\mathrm{p}=0.895>0.05$. 
Table 5. Teachers' attitudes toward nanotechnology.

\begin{tabular}{ccccc}
\hline Variable & $\mathbf{n}$ & $\bar{X}$ & $\mathrm{~S}$ & $\%$ \\
\hline $\begin{array}{c}\text { Attitude of the teachers' } \\
\text { toward Nanotechnology }\end{array}$ & 70 & 2.78 & 0.43 & $55.6 \%$ \\
\hline
\end{tabular}

Table 6. Students' attitudes toward nanotechnology.

\begin{tabular}{ccccc}
\hline Variable & $\mathbf{n}$ & $\bar{X}$ & $\mathbf{S}$ & $\%$ \\
\hline $\begin{array}{c}\text { Attitude of the students } \\
\text { toward Nanotechnology }\end{array}$ & 120 & 2.55 & 0.36 & $51.0 \%$ \\
\hline
\end{tabular}

Table 7. Attitudes of teachers with respect to gender.

\begin{tabular}{cccccc}
\hline Gender & $\mathbf{n}$ & $\bar{X}$ & $\mathrm{~S}$ & d.f & t-value \\
\hline Male & 40 & 2.80 & 0.49 & & 0.382 \\
Female & 30 & 2.75 & 0.35 & & \\
\hline
\end{tabular}

Table 8. Attitudes of students with respect to gender.

\begin{tabular}{cccccc}
\hline Gender & $\mathbf{n}$ & $\bar{X}$ & $\mathbf{S}$ & d.f & t-value \\
\hline Male & 55 & 2.56 & 0.37 & & \\
Female & 56 & 2.54 & 0.35 & 118 & 0.132 \\
\hline
\end{tabular}

\subsubsection{Responses with Respect to School Type}

Both teachers and students show similar results, with no significant difference between governmental and private schools. With $\mathrm{p}=0.93>0.05$ for teachers, and $\mathrm{p}=0.124>0.05$ for students respectively. (The results presented in Table 9 and Table 10).

\subsubsection{Responses with Respect to Years of Experience, and Educational Level for Teachers}

According to the number of years of experience, the teachers were divided to 3 groups: an experience less than 5 years, 5 - 10 years of experience, and more than 10 years, as shown in Table 11. With approximate values of arithmetic means for the three categorized groups, there is no significant effect of years of experience toward the teachers' attitudes toward nanotechnology. ANOVA test (Table 12), confirms the results with $\mathrm{p}=0.147>0.05$.

Among the 70 teachers, 24 have B.A degree, 30 with B.A + Diploma, whereas, the lowest number is for teachers who has M.A degree or more. The results show that there is no effect of educational degree, even though; the arithmetic value is the same with teachers who have B.A degree and M.A or more. ANOVA test confirmed the results with $p=0.226>0.05$ (Table 13 and Table 14).

\subsubsection{Responses with Respect to Grade Variable for Students}

The high-school students participated in this research, were from different grades, grade $10^{\text {th }}, 11^{\text {th }}$, and grade $12^{\text {th }}$. With approximated values of arithmetic 
means, and according to ANOVA test $(\mathrm{p}=142>0.05)$, the variable "grade" has no effect on the students' attitudes toward nanotechnology (Table 15 and Table 16).

\subsection{Interviews Held with Teachers and Students}

In addition to the quantitative data assembled via the questionnaires, a semi-structured questionnaire interview was conducted for randomly selected teachers and students. The questions and answers are presented in Table 17. According to the participants' answers in this interview, both teachers and students lack enough information about the field of nanotechnology.

Table 9. Attitudes of teachers with respect to school type.

\begin{tabular}{cccccc}
\hline School & $\mathbf{n}$ & $\bar{X}$ & $\mathbf{S}$ & d.f & t-value \\
\hline Governmental & 91 & 2.52 & 0.34 & & \\
Private & 29 & 2.64 & 0.41 & 118 & -1.551
\end{tabular}

Table 10. Attitudes of students with respect to school type.

\begin{tabular}{cccccc}
\hline School & $\mathbf{n}$ & $\bar{X}$ & $\mathrm{~S}$ & d.f & t-value \\
\hline Governmental & 52 & 2.78 & 0.44 & 68 & -0.079 \\
Private & 18 & 2.79 & 0.43 & & \\
\hline
\end{tabular}

Table 11. Teachers' attitudes towards nanotechnology, the effect of number of experience's years.

\begin{tabular}{cccc}
\hline Experience & $\mathbf{n}$ & $\bar{X}$ & $\mathrm{~S}$ \\
\hline Less than 5 years & 43 & 2.74 & 0.43 \\
$5-10$ years & 15 & 2.98 & 0.44 \\
More than 10 years & 12 & 2.70 & 0.43 \\
\hline
\end{tabular}

Table 12. ANOVA test, the effect of years of experience.

\begin{tabular}{ccccc}
\hline & SS & df & MS & F \\
\hline Between Groups & 0.727 & 2 & 0.363 & 1.970 \\
Within Groups & 12.359 & 67 & 0.184 & \\
Total & 13.086 & 69 & \\
\hline
\end{tabular}

Table 13. Attitudes of teachers towards nanotechnology, the effect of the educational level.

\begin{tabular}{cccc}
\hline Educational level & $\mathbf{n}$ & $\bar{X}$ & $\mathbf{S}$ \\
\hline B.A & 24 & 2.86 & 0.40 \\
B.A + Diploma & 30 & 2.68 & 0.48 \\
M.A and more & 16 & 2.86 & 0.37 \\
\hline
\end{tabular}


Table 14. ANOVA test, the effect of educational level of teachers.

\begin{tabular}{ccccc}
\hline & SS & df & MS & F \\
\hline Between Groups & 0.569 & 2 & 0.285 & \\
Within Groups & 12.517 & 67 & 0.187 & 1.523 \\
Total & 13.086 & 69 & & \\
\hline
\end{tabular}

Table 15. Attitudes of student from different grades towards nanotechnology.

\begin{tabular}{cccc}
\hline Grade & $\mathbf{n}$ & $\bar{X}$ & $\mathbf{S}$ \\
\hline 10 th & 34 & 2.66 & 0.34 \\
11 th & 65 & 2.51 & 0.37 \\
12 th & 21 & 2.53 & 0.36 \\
\hline
\end{tabular}

Table 16. Attitudes of student from different grades towards nanotechnology ANOVA test.

\begin{tabular}{ccccc}
\hline & SS & df & MS & F \\
\hline Between Groups & 0.514 & 2 & 0.257 & \\
Within Groups & 15.157 & 117 & 0.130 & 1.984 \\
Total & 15.671 & 119 & & \\
\hline
\end{tabular}

Table 17. Teachers and students' answers to the semi-structured interview.

\begin{tabular}{|c|c|c|}
\hline Question & Teachers' Answers & Students' Answers \\
\hline $\begin{array}{l}\text { What do you } \\
\text { know about } \\
\text { Nanotechnology? }\end{array}$ & $\begin{array}{l}\text { - I do not know anything about } \\
\text { Nanotechnology. } \\
\text { - I heard slightly of Nanotechnology } \\
\text { but I did not understand much. } \\
\text { - I just know little about } \\
\text { Nanotechnology. } \\
\text { - I read about it in some } \\
\text { websites without investigating } \\
\text { more about it. }\end{array}$ & $\begin{array}{l}\text { - It is the first time I hear of this } \\
\text { topic. } \\
\text { - We heard a lot about technology } \\
\text { and its development, but we never } \\
\text { paid any attention to this topic. } \\
\text { - I study science a lot but teachers } \\
\text { never mentioned this topic. }\end{array}$ \\
\hline $\begin{array}{l}\text { Which applications } \\
\text { do you know about } \\
\text { Nanotechnology? }\end{array}$ & $\begin{array}{l}\text { I do not know about } \\
\text { Nanotechnology other than the } \\
\text { development of medical industry. } \\
\text { - Nanotechnology is used much in } \\
\text { medicine. } \\
\text { - Nanotechnology has many fields } \\
\text { especially in the development of } \\
\text { different industries. }\end{array}$ & $\begin{array}{l}\text { - I do not know much about the } \\
\text { fields that Nanotechnology has } \\
\text { developed. } \\
\text { - I just know that Nanotechnology } \\
\text { has improved in medicine. } \\
\text { - My information is very slight about } \\
\text { the scientific applications of } \\
\text { Nanotechnology. It incorporates in } \\
\text { many fields but I do not exactly } \\
\text { know what these fields are. }\end{array}$ \\
\hline $\begin{array}{l}\text { Nanotechnology } \\
\text { deals with-------? }\end{array}$ & $\begin{array}{l}\text { - improvements in medicine } \\
\text { - medicine } \\
\text { - heard about Husam Hayek who } \\
\text { deals with artificial nose }\end{array}$ & $\begin{array}{l}\text { - We do not know many } \\
\text { Nonscientists because they are } \\
\text { not famous these days. } \\
\text { - I have never heard about this field. } \\
\text { - I did not understand } \\
\text { Nanotechnology in order to know } \\
\text { its research. }\end{array}$ \\
\hline
\end{tabular}




\section{Discussion}

The Arab sector in Israel represents $20 \%$ of Israel' population and considered as a minority in the country. Israel culture views higher education as the key to higher mobility and socioeconomic status in Israeli society. The emphasis of education within Israeli society has its modern roots, and Israel is considered as scientifically developed country. Despite this fact, nanoscience and nanotechnology which is considered as one of the key emerging interdisciplinary areas of the $21^{\text {st }}$ century, is not included in the teaching curriculum in schools (Hofstein et al., 2004). This article investigated the situation of the Arab minority in Israel, what information teachers and students are aware of about nanoscience and nanotechnology, and what are their attitudes toward it?

Our findings indicate that both teachers and students have basic or no enough knowledge about nanotechnology that confirm the research hypothesis. Nobody refer to the nano-meter scale specifically. Investigating the attitudes of teachers and students toward nanotechnology, their responses were at a low level and showed very superficial knowledge, which is not consistent with our hypothesis. Moreover, none of the variables examined, years of experience and level of education for teachers, grade for students, and school type, gender for both teachers and students has significant effect on the attitudes toward nanotechnology. Despite the fact that we expected that teachers with higher education levels, and more years of experience could show more expertise and acquire more developed topics. Taking into consideration that they undergo more training courses during the years. Other findings in the literature are consistent with our results. Toqeer and others (Toqeer et al., 2015) have found that the majority of respondents had heard about nanotechnology but only $47 \%$ had read about it, and a slightly lower percentage (44.4\%) had awareness of the applications of it. According to Ekli \& Sahin (2013), students from Turkish middle schools, have some awareness of nanotechnology and most students have positive opinions about it. A study conducted by Tanya Sheetz (2005) showed that only $17 \%$ of the respondents were able to identify what nanotechnology is, while men do have a high percentage vs. females that is inconsistent with our results. A research work was conducted in Germany (Fredric et al., 2010) in order to examine public attitudes and awareness toward nanotechnology revealed that the majority of the participants are not familiar with nanotechnology. According to Saji (George et al., 2014) public perceptions of nanotechnology in Singapore where technological innovation is an established part of the country economy, about $80 \%$ of respondents have "some" understanding of nanotechnology, 60\% report having heard some negative information and 39\% perceive nanotechnology as beneficial. Ekli and Sahin (2010) founded that science, technology teachers in Turkey have "moderate" information about nanotechnology that learned mostly from the things around, and their knowledge base was found to be inadequate, while the participants have positive attitudes toward nanotechnology. Our results also agree with Elmarzugi and others (Elmarzugi et al., 2014) who found that many 
Libyan students have displayed a favorable the Libyan undergraduate and postgraduate curriculum and education.

\section{Conclusion}

Nanotechnology and its importance have been recognized worldwide. It considered as one of the key emerging interdisciplinary areas of the $21^{\text {st }}$ century. Despite this fact, several studies show a low awareness and attitudes toward nanotechnology among public, teachers, and students. This study investigated awareness and attitude toward nanotechnology among science teachers and secondary school students from the Arab sector in Israel. The results founded low awareness and positive attitudes. It is very important to mention that teaching curriculum in Israel does not include the concept of nanotechnology, which proves the "poor" knowledge of teachers and students.

In light of the results of this study, we recommend that:

1) Science Teachers and students in the Arab sector in Israel should be made aware of Nanotechnology.

2) Training Courses, Workshops, should be held for science teachers in the Arab sector in order to raise their awareness and knowledge about nanotechnology.

3) Incorporating the subject of nanotechnology to teaching curriculum in schools.

\section{Conflicts of Interest}

The authors declare no conflicts of interest regarding the publication of this paper.

\section{References}

A'li, N., \& Da'as, R. (2016). Arab Women in Israeli Politics: Aspirations for Fundamental Equality or Preservation of Gender Inequality? Cultural and Religious Studies, 4, 67-86. https://doi.org/10.17265/2328-2177/2016.02.001

Abd-El-Khalick, F. (2001). Embedding Nature of Science Instruction in Preservice Elementary Science in Preservice Elementary Science. Journal of Science Teacher Education, 12, 215-233. https://doi.org/10.1023/A:1016720417219

Abu-Asbah, K. (2007). The Arab Education in Israel, Dilemmas of a National Minority. Publication No. 3/52.

Abu-Saad (2006). The Portrayal of Arabs in Textbooks in the Jewish School System in Israel. Israel Studies, 6, 74-86.

Arar, K. (2012). Israeli Education Policy since 1948 and the State of Arab Education in Israel. Italian Journal of Sociology of Education, 1, 113-145.

Bhushan, B. (2010). Springer Handbook of Nanotechnology. Berlin Heidelberg: Springer-Verlag. https://doi.org/10.1007/978-3-642-02525-9

Ekli, E., \& Sahin, N. (2010). Science Teachers and Teacher Candidates' Basic Knowledge, Opinions and Risk Perceptions about Nanotechnology. Procedia Social and Behavioral Sciences, 2, 2667-2670. https://doi.org/10.1016/j.sbspro.2010.03.392

Ekli, E., \& Sahin, N. (2013). Nanotechnology Awareness, Opinions and Risk Perceptions 
among Middle School Students. International Journal of Technology and Design Education, 23, 867-881. https://doi.org/10.1007/s10798-013-9233-0

Elmarzugi, N. A., Keleb, E. I., Mohamed, A. T., Benyones, H. M., Bendala, N. M., Me-hemed, A. I., \& Eid, A. M. (2014). Awareness of Libyan Students and Academic Staff Members of Nanotechnology. Journal of Applied Pharmaceutical Science, 4, 110-114.

Farshchi, P., Sadrnezhaad, S., Nejad, N., Mahmoodi, M., \& Abadi, L. (2011). Nanotechnology in the Public Eye; the Case of Iran, as a Development Country. Journal of Nanoparticle Research, 13, 3511-3519. https://doi.org/10.1007/s11051-011-0274-6

Fredric, V., Sandrine, B., Andrea, B., Stephan, M., \& Jutta, R. (2010). The Morality of Attitudes toward Nanotechnology: about God, Techno-Scientific Progress, and Interfering with Nature. Journal of Nanoparticle Research, 12, 373-381.

George, S., Kaptan, G., Lee, J., \& Frewer, L. (2014). Awareness on Adverse Effects of Nanotechnology Increases Negative Perception among Public: Survey Study from Singapore. Journal of Nanoparticle Research, 16, 2751.

https://doi.org/10.1007/s11051-014-2751-1

Ho, S., Scheufele, D., \& Corley, E. (2011). Value Predispositions, Mass Media, and Attitudes toward Nanotechnology: The Interplay of Public and Experts. Science Communication, 33, 167-200. https://doi.org/10.1177/1075547010380386

Hofstein, A., Shore, R., \& Kipnis, M. (2004). Providing High School Chemistry Students with Opportunities to Develop Learning Skills in an Inquiry-Type Laboratory: A Case Study. International Journal of Science Education, 26, 47-62.

https://doi.org/10.1080/0950069032000070342

Joachim, S. (2004). Multidisciplinarity, Interdisciplinarity, and Patterns of Research Collaboration in Nanoscience and Nanotechnology. Scientometrics, 59, 425-465. https://doi.org/10.1023/B:SCIE.0000018542.71314.38

Kahan, D. M. (2009). The Evolution of Risk Perceptions. Nature Nanotechnology, 4, 705-706. https://doi.org/10.1038/nnano.2009.329

Likert, R. (1932). A Technique for the Measurement of Attitudes. Archiv für Psychologie, 140, 1-55.

Putnam, R. T., \& Borko, H. (2000). What Do New Views of Knowledge and Thinking Have to Say about Research on Teacher Learning? Educational Researcher, 29, 4-15. https://doi.org/10.3102/0013189X029001004

Roco, M. C. (2003). Converging Science and Technology at the Nanoscale: Opportunities for Education and Training. Nature Biotechnology, 21, 1247-1249. https://doi.org/10.1038/nbt1003-1247

Roco, M. C., \& Bainbridge, W. (2005). Societal Implications of Nanoscience and Nanotechnology: Maximizing Human Benefit. Journal of Nanoparticle Research, 7, 1-13. https://doi.org/10.1007/s11051-004-2336-5

Sheetz, T., Vidal, J., Pearson, T. D., \& Lozano, K. (2005). Nanotechnology: Awareness and Societal Concerns. Technology in Society, 27, 329-345. https://doi.org/10.1016/j.techsoc.2005.04.010

Sjøberg, S., \& Schreiner, C. (2010). The ROSE Project. An Overview and Key Findings. http://roseproject.no/network/countries/norway/eng/nor-Sjoberg-Schreiner-overview2010.pdf

Toqeer, A., Saba, I., Khawaja, Y., \& Sayed, M. R. (2015). Awareness and Attitude about Nanotechnology in Pakistan. Journal of Nano Education, 8, 44-51.

https://doi.org/10.1166/jne.2015.1074 
Wacker, M. G. (2014). Nanotherapueutics-Product Development along the "Nanomaterial" Discussion. Journal of Pharmaceutical Sciences, 103, 777-784. https://doi.org/10.1002/jps.23879

Waldron, A., Spencer, D., \& Batt, C. (2006). The Current State of Public Understanding of Nanotechnology. Journal of Nanoparticle Research, 8, 569-575.

https://doi.org/10.1007/s11051-006-9112-7 